\title{
Nytt og nyanserende om Hartvig Nissen
}

\section{Harald Thuen}

\section{Professor, Høgskolen i Innlandet}

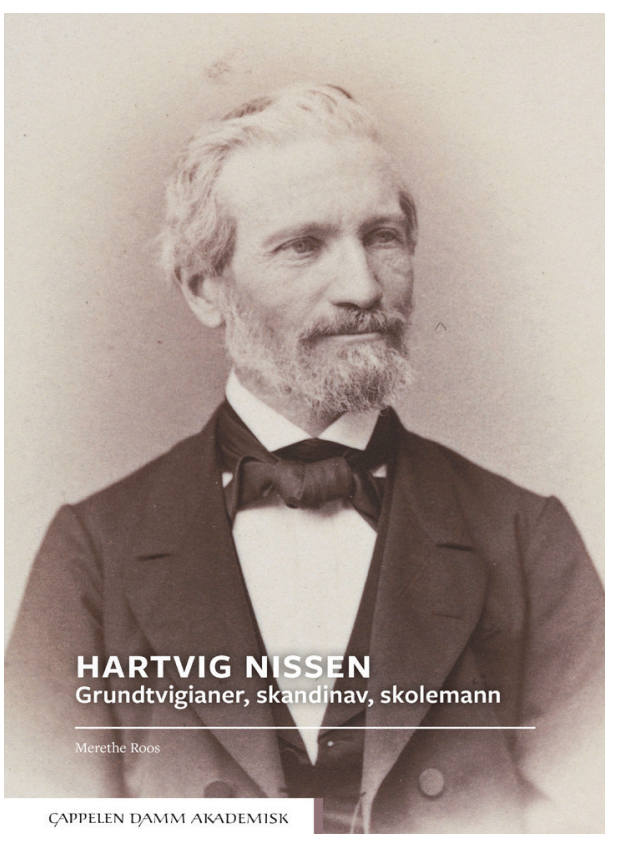

Merethe Roos: Hartvig Nissen. Grundtvigianer, skandinav, skolemann. Cappelen Damm Akademisk, 2019, 282 sider.

Historikeren Merethe Roos har gitt seg i kast med Hartvig Nissen (1815-1874), en av Norges mest betydningsfulle skolereformatorer gjennom tidene. Roos' beretning er ikke en biografi om livshistorie og personlighet i tradisjonell forstand, men heller det vi kan kalle en intellektuell biografi: en profil av Nissens tenkning og hva han sto for i utdannings- og opplysningsspørsmålet. Som bokens undertittel sier, er det i første rekke Nissen som grundtvigianer og skandinav vi møter. Det er en interessant og utdypende studie ikke bare av Nissen, men også av samtidens åndsliv, bevegelser og miljøer. Jeg vender tilbake til det, men først litt om hvem Nissen var og hvilken epoke i utdanningshistorien vi står overfor.

Korrespondanse: Harald Thuen, epost: Harald.Thuen@inn.no

(C) 2020 Harald Thuen. This is an Open Access article distributed under the terms of the Creative Commons Attribution 4.0 International License (https://creativecommons.org/licenses/by-nc/4.0/), allowing third parties to copy and redistribute the material in any medium or format and to remix, transform, and build upon the material for any purpose, even commercially, provided the original work is properly cited and states its license. 


\section{Harald Thuen}

\section{Nissen og skolereformene}

Hartvig Nissen var prestesønn fra Trøndelag og ble filolog ved Universitetet i København. Ved inngangen til 1840-årene vendte han hjem til Norge og hovedstaden, og etablerte her to privatskoler på høyere nivå; en for gutter og en for jenter - sistnevnte opphavet til nåværende Hartvig Nissens skole. Etter hvert gikk han inn i utdanningspolitikken og ble en skarp debattant med polemisk sting særlig i spørsmål om allmueskolens og den lærde skolens utvikling. Vi er inne i modernitetens brytningsår, en skjellsettende tid i norsk og vestlig utdanningshistorie. 1700-tallets kirkeskole står for fall, likeså latinskolens nedarvede dannelsesidealer som utfordres av realismens nyttetenkning - «Tidens Krav», som det gjerne het. Ideer om det autonome mennesket som selv tar myndighet over sitt liv la føringer for en ny utdanningstenkning.

Omgangsskolens tid er forbi; nå er det fastskoler, nytt faginnhold, ny skolearkitektur, bedre kvalifiserte lærere, nye prinsipper for offentlig finansiering av skolen, bedre lønninger og ny administrasjonsstruktur med egne skoledirektører som gjelder. Hartvig Nissen tar rollen som reformarbeidets lederskikkelse. Han ble, framfor noen, embetsmannsstatens "skoleekspert», i enkelte år innenfor departementets vegger, i andre utenfor i konflikt med departementsledelsen. Reformprosessene kulminerer med to epokeskapende skolelover, den første langt på vei ført i pennen av Nissen, den andre med Nissen som kommisjonsmedlem: allmueskoleloven for landet (1860) og lov om høyere skoler, eller som det het, skoler for «den høiere Almendannelse» (1869). Begge pekte framover: på kort sikt mot folkeskolelovene og gymnasloven, innførte før 1800-tallet var omme, i lengre perspektiv mot 1900-tallets enhetsskole og et sammenhengende utdanningssystem.

Det er denne viktige og avgjørende perioden for skolens utvikling Merethe Roos tar oss inn i. Hartvig Nissens virke og betydning er behandlet i tidligere forskning og viet behørig plass i allmenn utdanningshistorisk litteratur. Einar Boyesens voluminøse doktorgradsavhandling, tobindsverket Hartvig Nissen 1815-1874 og det norske skolevesens reform (1947), utgiør fortsatt det mest omfattende bidraget. Senere har Rune Slagstads framstilling av Nissen som «nasjonal strateg» bidratt til fornyet interesse (Slagstad: De nasjonale strateger, 1998). Men historieforskningen er ikke en forskning for de endelige punktum. Nye forskergenerasjoner kommer til og ser historien i perspektiv av sin tid, de finner nye «lamper» å lyse opp stoffet med, og kanskje leter de også fram nye kilder.

\section{Bokens tema}

Roos har gjort "nærstudier av en rekke tekster som ikke har vært belyst tidligere», sies det på bokens omslagsside, og hun har funnet brevmateriale som ikke har vært anvendt tidligere. Hennes overordnede spørsmål er: Hva var formende for Nissen som skolemann og utdanningsstrateg? Som i tidligere utdanningshistorisk forskning dreier det seg mye om motiver og inspirasjonskilder: Hvor kom ideene fra og hvordan 
vant de innpass? At Nissen var grundtvigianer og skandinav visste vi nok, det er kjent fra tidligere forskning, men at dette var så grunnleggende for ham som Roos nå søker å vise, så å si kjølstokken for hans tenkning, er en ny og interessant vinkling. Tidligere forskning med Boyesen i spissen har vært særlig opptatt av å vise hvilke pedagogiske ideer (Herbart, Beneke, Madvik, Lange) Nissen var inspirert av. Roos underkjenner ikke denne forskningen, men hun ønsker å se Nissens virke mot et mer sammensatt bakteppe. Hun argumenterer for at Nissens karriere og posisjon «i atskillig større grad enn hva man har fått fram tidligere» var betinget av grundtvigianismen og skandinavismen - en nordisk fellesskapsorientering dypt inspirert av det grundtvigianske miljøet i Danmark, men i stor grad også med bånd til åndsliv og skoletenkning i Sverige. Disse to nært sammenvevde linjene, grundtvigianismen og skandinavismen, er bokens ledetråder som vi følger i tre hovedfaser fra studietiden i København på slutten av 1830-tallet fram til Nissens avsluttende karriere fram mot 1870-årene. La oss se litt nærmere på de enkelte fasene.

\section{8-1849}

I dette første tiåret møter vi i Nissen som filologistudent i København fram til han etablerer seg som skolemann i Kristiania. Det skjer her et «brudd» i Nissens karriereplaner, tidfestet til 1843 av Roos: Han legger nå forskerambisjonene på hyllen og vier sitt profesjonelle liv helt og fullt til utdannings- og opplysningssaken. Studietiden gir nøkkelen til Nissens virkelighetsforståelse og utdanningstenkning, som Roos ser det. Og da er det ikke fortrinnsvis studiene i indoeuropeisk filologi (sanskrit) hun sikter til, men de personlige forbindelsene, nettverket og miljøet han vanker i. Kjernefiguren er N. F. S. Grundtvig, som miljøet beundrer og dyrker nærmest som en helt. Boken går inn på Grundtvigs forfatterskap, tenkning og språkform i spørsmål bl.a. om skolen og morsmålets betydning. Roos gir inngående beskrivelser av miljøet, toneangivende personer, selskaper og tidsskrifter som tilhørte kretsen. Nissens Københavnopphold falt $\mathrm{i}$ tid sammen med årene da grundtvigianismen tok form av være en folkebevegelse. Grundtvig fikk nå tale fritt, og han gikk offensivt og energisk til oppgaven. Roos søker å vise at det går «en direkte linje» fra tiden i København på slutten av 1830-årene fram til reformvedtakene i Norge i 1860-årene. Studietiden var for Nissen også en døråpner for skandinavismen, som på sikt la grunnlaget for at Nissen ikke bare vendte seg til Danmark i utdanningsspørsmålet, men i betydelig grad også til Sverige.

\section{$1850-1860$}

Dette er tiåret da Nissen etablerer seg som folkeopplyser og utdanningsreformator i Norge. 1850 har i utdanningshistorien blitt sett på som et gjennombruddsår for organisasjonstanken, ikke minst i lys av lærerforeningene som nå begynte å gjøre seg gjeldende. Året etter ble Selskabet for Folkeopplysningens Fremme stiftet, med 


\section{Harald Thuen}

Nissen som leder fram til 1857, og med husmannssønnen og seminaristen Ole Vig som redaktør av selskapets tidsskrift Folkevennen, en sentral kanal i formidling av opplysningsideene. Noe av det viktigste for opplysningsselskapet var å oppdra befolkningen til «demokratiske og autonome borgere», poengterer Roos. Hun viser hvordan Nissens demokratiforståelse var grunnleggende forskjellig fra Marcus Thranes forståelse. Mens Thrane og hans arbeiderbevegelse agiterte for demokratiske rettigheter, i første hånd allmenn stemmerett for menn, løftet Nissen og opplysningsselskapet fram demokratiets menneskelige verdier - «demokrater i kraft av å ha kommet til seg selv som mennesker». I Grundtvigs ånd handlet demokratiet om å danne og opplyse folket slik at mennesket ble skikket som menneske og kunne gis politisk myndighet. Ved å «overrisle» folket med kunnskap og opplysning vekket man borgerne til lydighet overfor stat og rett, og folket evnet å gjennomskue opprørske bevegelser som thranittene. Slik ble også skolen i Nissens tenkning knyttet til menneskets myndiggjøring i det å utvikle elevene til frie, selvstendige og gode samfunnsborgere. Roos' diskusjon av tidens demokratitenkning (der hun for øvrig også gjør undertegnede en kritisk visitt) gir et nyansert og utfyllende bilde av disse viktige årene i utdanningshistorien.

1850-årene kan ikke passere uten en granskning av Nissens forarbeider til allmueskoleloven av 1860, så heller ikke hos Roos. Tidligere forskning har vært mye opptatt av de organisatoriske sidene i Nissens reformideer, der han legger grunnlaget for å se skolens lavere og høyere trinn i sammenheng og planter spiren til enhetsskolen. Roos er ikke fortrinnsvis opptatt av disse sidene ved reformene, men spør heller hva som lå til grunn for hans organisatoriske modeller: hvorfor han tenker som han gjør. Og igjen finner hun avspeil av Grundtvig. Leser jeg Roos riktig, er det altså ikke tanken om organisatorisk enhet i seg selv, politisk motivert i sosiale og nasjonaløkonomiske hensyn, som er Nissens hovedmotiv, men ideen om "dannelse av en felles ånd». Dannelsen av "fellesånden» ser Nissen «som opplysningens egentlige mål», og videre, opplysning hos Nissen kan forstås "som en dialektisk prosess». På denne måten nyanserer Ross bildet vi har av reformmotivene fra tidligere forskning, men hun kunne gjerne diskutert og utdypet dette i lys av en bredere politisk kontekst nasjonalt og internasjonalt. Det ligger nær innvendende å spørre: Kan det ha vært andre, dypere motiver enn opplysningsselskapets og grundtvigianismens dannelsesmotiv som stakk under i utviklingen av reformplanene?

Sommeren 1854, på den verdensomspennende skoleutstillingen i London, stiftet Nissen personlig bekjentskap med svensken Per Adam Siljeström - en bredt orientert skolemann, forfatter og naturviter. Han ble en viktig samtalepartner og inspirator for Nissen i utdanningsspørsmålet fram mot reformene i 1860-årene, ja, så pass viktig at Roos mener vi kan se en dreining i Nissens forfatterskap etter kontakten med Siljeström knyttet til spørsmålet om verdsliggjøring av skolen. Kontakten mellom Nissen og Siljeström er kjent fra Boyesens avhandling, men Roos går lenger i sin tolkning av kontaktens betydning, og underbygger med det ytterligere sitt resonnement om Nissens skandinavisme. Hun konkluderer med at det trolig har vært tettere forbindelser mellom Sverige og Norge i utdanningstenkningen enn det som har 
framkommet tidligere, der tilknytningen til Danmark heller enn Sverige har vært løftet fram.

\section{0-1874}

Nissens siste fase skriver Roos forholdsvis kort om. Det er nå han blir Kirkedepartementets leder som ekspedisjonssjef (1865) og tar aktivt del i reformarbeidet som førte fram til loven om den høyere skolen av 1869. Denne loven har vanligvis blitt sett på som det innledende bruddet - «den første bresjen» - med latinskolen og nyhumanismens hegemoni. Kampen mellom klassisismen og realismen hadde kommet til et sluttpunkt ved en deling av den høyere skolen i to linjer: latingymnas og realgymnas. Rett nok sto den klassiske dannelsen fortsatt sterkt, men nå mer avgrenset til en separat del av skolen. Når Roos så skriver at Nissens reformforslag, der han presenterer ideen om en todeling av gymnaset, er «blitt sett som nyhumanismens seier over realismen i den norske skole» (s. 248), er det egnet til undring: nyhumanismens seier over realismen? Her er ingen referanser, hvilken forskning siktes det til? I pedagogisk-historisk forskning er det vanligvis beskrevet omvendt, eller moderert, at 1869loven var et første kompromiss på veien mot realismens seier (jf. f.eks. Helge Dahl, Reidar Myhre). Myhre bruker eksempelvis en slik overskrift om utviklingen i den høyre høyere skolen mellom 1848 og 1896: "Realdannelsens og encyklopediens seier i den norske skolen» (Den norske skoles utvikling, 1994).

Nissens posisjon i striden mellom nyhumanismen og realismen er særlig interessant fordi han er reformenes hovedarkitekt. Politisk er det nærliggende å se ham som «kompromissets mann» i en søken etter å utforme et encyklopedisk kunnskapsinnhold bestående av både nyhumanismens og realismens fag. Fagkompromisset speiles også i reformenes nye fellesbegrep, allmenndannelse. Roos går ikke inn i denne diskusjonen, heller ikke i særlig grad på Nissens manøvrer i og utenfor departementet, i det hele tatt hans posisjon, miljøer og nettverk i kontekst av embetsmannsstaten. Kapittelet og fasens overskrift er "ekspedisjonssjef, reformator, skandinavisk protagonist». Den inviterer til en politisk analyse av Nissen. Hvilke føringer la statens styringsformer for reformene? Hvordan var forholdet mellom den offentlige og private sfære i skolespørsmålet? Med sin privatskolevirksomhet og som reformator hadde Nissen en fot i begge sfærer, hvordan spilte det inn på hans rolle som politisk aktør? Tema som dette tar Roos knapt opp. Det er synd, for nettopp i perspektivet av å se Nissen som grundtvigianer og skandinav kunne hun her utfylt bildet av ham som politisk strateg.

\section{Idésammenfall}

Tiårene rundt 1850 var så visst en tid for debatt og nye ideer. Roos beskriver innsiktsfullt hvordan miljøene, nettverkene og kontaktene over landegrensene i Skandinavia utviklet seg. Hun viser gjennom nærlesning hvordan grundtvigianismen kan gjenkjennes ikke bare i innhold, men også i språkstil og ordvalg. Epokens åndsliv 


\section{Harald Thuen}

var sammensatt: nyhumanismen, realismen, kontinental pedagogikk, grundtvigianismen, folkeopplysningsideene og skandinavismen. Alle hadde de sine talsmenn, alle spilte de inn mot opplysnings- og utdanningsspørsmålet. I politikk og administrasjon hadde en ny generasjon embetsmenn tatt sete; de sto for en ideologisk fornyelse, dypt inspirert av klassisk liberalistisk tenkning og rettsstatsideologi. Embetsmennene reiste og skrev bindsterkt om hva de så og fant i utlandet. Også Hartvig Nissen, som utforsket skolevesenet i flere land, blant annet Skottland. Denne reisen resulterte $i$ en 500 siders bok der han også presenterte grunnlaget for en allmueskolereform i Norge.

Som vi skjønner kunne inspirasjonskildene være mange, noen samstemte, noen på tvers. Det er ikke umiddelbart enkelt å fastslå hva som kan ha virket formende på Nissens utdanningstenkning, hva som var viktigere enn annet for hans ståsted i politikk og pedagogikk. Tidligere forskning har løftet fram Nissens påvirkning av kontinental og dansk pedagogikk. I Danmark høstet han særlig av J. N. Madviks tenkning, kontinentalt og overordnet var assosiasjonpsykologien og J. F. Herbart ledestjernen. Det er stort overlapp mellom grundtvigianismens og herbartianismens pedagogiske ideer, eksempelvis i språkundervisning og i undervisningsprinsippet om å starte i det assosiative gjenkjennbare og nære stoffet. Roos diskuterer ikke idésammenfall som dette, men er innom problemet når hun skriver slik:

I Nissens tekster blandes grundtvigiansk tankegods med nyere pedagogiske innsikter ... Hans målsetting om hva mennesket skal være i stand til å bidra med i samfunnet og hans dannelsesprosjekt hviler tungt på Grundtvig, mens hans forståelse av hvilke mentale forutsetninger det enkelte menneske har i seg for at dette skal finne sted, bygger på innsikter som Nissen henter fra nyere pedagogisk teori, mer spesifikt Johann Friedrich Herbart (s. 176).

Dette er en løsning av problemet, en todeling forent i Nissens hode, kan det forklares så enkelt?

Roos holder fast ved sitt utgangspunkt fra begynnelse til slutt: å overbevise leseren om at nøkkelen til Nissen ligger i grundtvigianismen og skandinavismen. Hun er standhaftig, hun hamrer inn sitt budskap belegg for belegg. Ja, til tider, når hun enda en gang vender tilbake til sitt hovedpoeng, er det nesten som hun tviler på overbevisningskraften i det hun tidligere har sagt. Men så gjør hun også bruk av et variert kildemateriale, og viser langs flere veier hvordan Nissens tenkning formes augmentativt og språklig. Roos' studie er et nyanserende bidrag til innsikt i 1800-tallets utdanningshistorie. 